\title{
MONOCLONAL ANTIBODIES USED FOR THE CHARACTERIZATION OF THE TWO PUTATIVE IRON-SULPHUR CENTRE PROTEINS ASSOCIATED WITH PHOTOSYSTEM I
}

\author{
by \\ GUNILLA HØYER-HANSEN", LISBETH SKOU HØNBERG ${ }^{(2)}$ \\ and DAVID J. SIMPSON" \\ "Department of Physiology, Carlsberg Laboratory, \\ Gamle Carlsberg Vej 10, DK-2500 Copenhagen, Valby \\ and \\ ${ }^{21}$ Institute of Genetics, University of Copenhagen \\ Øster Farimagsgade 2A, DK-1353 Copenhagen K.
}

Keywords: Barley, thylakoid polypeptides, immune-blot assay, viridis- $z b^{63}$, protoplasts, SDSpolyacrylamide electrophoresis, amino acid composition, electroelution

Monoclonal antibodies have been produced to the two putative 18.3 and $15.2 \mathrm{kD}$ iron-sulphur centre proteins in barley. When photosystem I particles, containing only chlorophyll $a$-protein 1 and the 18.3 and $15,2 \mathrm{kD}$ proteins, were used as the antigen, thirteen independent clones secreting either IgG or IgM antibodies against the $15.2 \mathrm{kD}$ protein were formed. No hybridomas secreting antibodies to the $18.3 \mathrm{kD}$ protein were detected. When a delipidated polypeptide preparation was the immunogen, we obtained one hybridoma, secreting antibodies of the IgM class to the $18.3 \mathrm{kD}$ protein.

These antibodies were used in immune-blot assays. Neither the 18.3 nor $15.2 \mathrm{kD}$ putative iron-sulphur centre proteins were detected in etioplast membranes. However, in the chloroplast membranes of the photosystem 1 mutant viridis- $z b^{\text {n.3 }}$ we found small amounts of these proteins.

The two proteins were purified by electroelution and then tested by immune-blot assay. Fractions with positive reaction were collected and the amino acid compositions determined. There were significant differences in the amounts of serine, glycine and histidine between the two proteins.

\section{INTRODUCTION}

By comparing electrophoretograms of wildtype barley thylakoid polypeptides with those of mutants with impaired photosystem I (PSI) activity, four polypeptides are found to be deficient or lacking in these mutants $(13,29,31)$. The apparent molecular weights of these polypeptides are $110,18.3,15.2$ and $14.8 \mathrm{kD}$. The

Abbreviations: BSA = bovine serum albumin; $\mathrm{Chl}_{a}-\mathrm{Pl}=$ chlorophyll a-protein 1 ; C/M PBS-wash $=$ the four polypeptides released from chloroform/methanol extracted thylakoids with PBS; DMEM = Dulbecco's modified Eagles' medium; DTT = dithiothreitol; ELISA = enzyme-linked immuno-adsorbent assay; EPR = electron paramagnetic resonance; $\mathrm{Fe}-\mathrm{S}=$ iron-sulphur; $\mathrm{Ig}=$ immunoglobulin; $\mathrm{kD}=$ kilodalton; $\mathrm{NBC}=$ newborn calf serum; PAGE = polyacrylamide gel electrophoresis; $\mathrm{PBS}=$ phosphate buffered saline; $\mathrm{PSI}=$ photosystem $\mathrm{I} ; \mathrm{SDS}=$ sodium dodecyl sulphate; Tris = tris-(hydroxymethyl)-aminomethane; $\mathrm{WT}=$ wild-type. 
$110 \mathrm{kD}$ polypeptide is the chlorophyll $a$-protein 1 containing the reaction centre $(P 700)$ of PSI $(14,28)$. The chlorophyll $a$-protein 1 and the 18.3 and $15.2 \mathrm{kD}$ polypeptides are also the constituents of a PSI particle capable of PSI electron transport (29). It has beeen proposed that the 18.3 and $15.2 \mathrm{kD}$ polypeptides carry two of the Fe-S centre on the reducing side of PSI (29). This has been inferred from in vivo labelling experiments with the radioisotope ${ }^{59} \mathrm{Fe}$. Most of the radioactivity was incorporated into cytochrome $f$, and the rest of the label was found in chlorophyll $a$-protein 1 and two polypeptides with electrophoretic mobilities similar to those of the two low molecular weight polypeptides of the PSI particle $(26,29)$. While it is clear that these polypeptides are involved in PSI activity (30), it is not certain that both polypeptides contain $\mathrm{Fe}-\mathrm{S}$ centers. It has been suggested that centers A and B are both located on the same polypeptide (10), Recently a more complex PSI particle from spinach consisting of 5 major polypeptides $(110,20,17,16.5,10 \mathrm{kD})$ has been analysed for identification of Fe-S centres (24). Upon in vivo labelling with ${ }^{35} \mathrm{~S}$ the $110,20,17$ and $16.5 \mathrm{kD}$ polypeptides showed radioactivity, as did peptides with an apparent molecular weight of $8 \mathrm{kD}$. The 20 and $17 \mathrm{kD}$ polypeptides are likely to be the same as the 18.3 and $15.2 \mathrm{kD}$ polypeptides from barley. LAGOUTTE, SETIF and DURANTON (24) suggest the Fe-S proteins to be among the $8 \mathrm{kD}$ polypeptides.

The barley PSI particle has been studied by electron paramagnetic resonance spectrometry (EPR) (30). These studies revealed that the PSI particle carries the reaction centre chlorophyll $P 700$ and the four electron acceptors $\mathrm{A}_{1}, \mathrm{X}, \mathrm{B}$ and $A$. The $A, B$ and $X$ signals come from membrane bound $\mathrm{Fe}-\mathrm{S}$ sulphur centres and $\mathrm{A}_{1}$ might be a pheophytin molecule or a special chlorophyll radical $(7,12)$. The EPR signals $P 700, A_{1}, X, B$ and A were all absent from the PSI mutant viridis- $z b^{63}(30)$.

The identification and characterization of polypeptides can also be achieved with the aid of specific antibodies (20). We report here the establishment of hybridoma lines secreting monoclonal antibodies to the two putative Fe-S centre proteins. With the aid of these monoclonal antibodies, using the immune-blotting technique, it has been possible to further characterize the two polypeptides of apparent molecular weight 18.3 and $15.2 \mathrm{kD}$.

\section{MATERIALS AND METHODS}

\subsection{Plant material}

Seeds of wild-type barley (Hordeum vulgare cv. Svalof's Bonus) and the recessive nuclear gene mutant viridis- $z b^{63}$ were germinated in tap water moistened vermiculite. They were grown in the dark or in the light ( 1700 lux) at $23^{\circ} \mathrm{C}$. In all experiments the seedlings were harvested seven days after sowing. The mutant seedlings were separated from the wild-type phenotype by their paler green colour.

\subsection{Isolation of PSI particles, Fe-S centre proteins, protoplasts and purified thylakoids}

Photosystem I particles were isolated using the zwitterionic detergent Empigen BB (29). The polypeptides of apparent molecular weight $32,000,23,000,18,300$ and 10,000 were extracted from thylakoid membranes with chloroform:methanol $(2: 1 \mathrm{v}: \mathrm{v})$, followed by a treatment with phosphate buffered saline $\mathrm{pH} 7.2$ (C/M PBS-wash) (15). The two putative Fe-S centre proteins were obtained by electroelution (19). Protoplasts from wild-type and viridis- $z b^{63}$ leaf slices were prepared according to published procedures (6). Internal plastid membranes were purified by flotation in a discontinuous sucrose gradient (21). If the membranes were not used immediately they were frozen in small aliquots in $0.1 \mathrm{M}-\mathrm{Na}_{2} \mathrm{CO}_{3}-0.1 \mathrm{M}$-DTT at $-20^{\circ} \mathrm{C}$. Chlorophyll was determined according to ARNON (1) and protein according to LowRY (25). Amino acid analysis was carried out after hydrolysis of the protein in $5.7 \mathrm{~N}-\mathrm{HCl}$ at $110^{\circ} \mathrm{C}$ for 24 hours in evacuated sealed tubes.

\subsection{SDS-PAGE and electrophoretic blotting procedure}

Electophoresis in SDS was performed as described by CHUA and BENNOUN (4). Immediately after completion of the electrophoretic run the polypeptides were transferred from the SDS- 
gel to nitrocellulose filters (Millipore HAHY pore size $0.45 \mu \mathrm{m}$ ) using $125 \mathrm{mM}$-Tris, 192 mM-glycine $\mathrm{pH} 8.9,20 \%(\mathrm{v} / \mathrm{v})$ methanol as the transfer buffer $(17,37)$. The electrotransfer was performed for 2.5 hours at $2 \mathrm{~A}$ and $60 \mathrm{~V}$ in a chromatography chamber with electrodes of acid-hardened stainless steel. The chromatography chamber was placed in ice during the electrotransfer. Immediately after transfer the nitrocellulose filters were cut into strips and kept in the dark at room temperature until used for immune-blot assays. Reference strips were stained with Amido black ( $0.1 \%$ in $45 \%$ methanol $/ 10 \%$ acetic acid) and destained in methanol/ water/acetic acid $(2 \mathrm{v} / 2 \mathrm{v} / 0.4 \mathrm{v})$. SDS-gels were stained with Coomassie blue. For calibration of molecular weight and transfer efficiency the following proteins were used: catalase, ovalbumin, chymotrypsinogen A, cytochrome C (Combithek, Boehringer Mannheim).

\subsection{Immune-blot assay (37)}

The nitrocellulose filter strips with the immobilized antigens were soaked for one hour at 37 ${ }^{\circ} \mathrm{C}$ in $10 \%$ newborn calf serum (NBC) in phosphate buffered saline (PBS) pH 7.2. They were then washed with three changes of PBS and incubated for $1-2$ hours at $37^{\circ} \mathrm{C}$ with hybridoma supernatant or purified monoclonal antibody $(40-50 \mu \mathrm{g} / \mathrm{ml})$ in $10 \% \mathrm{NBC}$ in PBS. After washing five times in $1 \%$ bovine serum albumin (BSA) in PBS, the strips were incubated for 1-2 hours with peroxidase-conjugated rabbit immunoglobulins to mouse immunoglobulins (Dako immunoglobulins a/s cat. no. P161). The secondary antibody was diluted 500-fold with $10 \%$ NBC in PBS. The strips were washed five times with PBS before the colour was developed with the aid of o-dianisidine as described in (37) or with 3-amino-9-ethylcarbazole (11).

\subsection{Enzyme-linked immunoadsorbent assay (ELISA).}

Sterile round-bottom microtestplates (Nunc cat. no. 252162) were incubated for 2 hours with $0.5 \mu \mathrm{g}$ protein per well of thylakoid membranes or PSI particles. The assay was carried out as described previously (16).

\subsection{Immunization}

Female mice (Balb/c strain, Bomholtgaard, Ry, Denmark) were injected intraperitoneally with PSI particles or C/M PBS-wash. Two immunization schedules were used (Table I). The first injection was given when the mice were 5-6 weeks old.

\subsection{Myeloma line}

The two myeloma lines used, X63-Ag8.6.5.3 (22) (Fusion A) and Sp2/0-Ag 14 (Fusion B) (33), were obtained from Dr. G. KöHLER. These lines do not produce any myeloma globulin chains. The myeloma lines and all the hybridoma lines (beginning 1 month after fusion) were grown in Dulbecco's modified Eagles' Medium (DMEM) supplemented with $1 \mathrm{mM}$ sodium pyruvate, 100 units penicillin-streptomycin/ml, 2 mm-glutamine, 0.05 mM-2-mercaptoethanol and $10 \%(\mathrm{v} / \mathrm{v})$ fetal calf serum. This medium is referred to as complete DMEM.

\subsection{Fusion}

Fusion A (Table I) was carried out as described by FAZEKAS DE ST.GROTH and SCHEIDEGGER (8) plating the fused cells out in microtestplates (Nunc, cat. no. 167008). In fusion B the procedure was slightly modified by increasing the myeloma and spleen cell number by three times to $3 \times 10^{8}$ myeloma cells and $1.8 \times 10^{8}$ spleen cells. During fusion $6 \mathrm{ml}$ of $50 \%(\mathrm{w} / \mathrm{v})$ polyethylene glycol 4000 (Merck, cat. no. 9727) in $10 \mathrm{~mm}$-sodium phosphate, $137 \mathrm{~mm}-\mathrm{NaCl}, 5 \mathrm{~mm}-\mathrm{KCl}, 10$ $\mathrm{mM}$-glucose, $10 \mathrm{mg}$ phenol red was added. However, the fused cells were resuspended in the same final volume of HAT-media (complete DMEM supplemented with $0.1 \mathrm{mM}$-hypoxanthine, $4 \times 10^{-7} \mathrm{M}$-aminopterin, $1.6 \times 10^{-5} \mathrm{M}$-thymidine) before plating out as in fusion A (48 $\mathrm{mls}$ ). This means that the cell concentration in each well was three times greater in fusion $B$ compared to fusion A.

The hybridoma clones formed were initially screened for antibody production using the ELISA assay with thylakoid membranes as antigens. Positive clones were transferred to 24 well Multidishes (Nunc, cat. no. 143982) and aminopterin was omitted from the media. When the 
cells showed confluent growth in the Multidish, the hybridoma clones were tested for antibody specificity by immune-blot assay. The antigens were either total thylakoid membrane polypeptides or PSI particle polypeptides. Cells secreting the desired antibodies were cloned by limited dilution (32) in microtest plates employing $10^{4}$ macrophages per well. The selected clones were grown in complete DMEM in $260 \mathrm{ml}$ tissue culture flasks (Nunc, cat. no. 153732) and the hybridoma supernatant was collected and used directly for assays or pooled and frozen for later use.

\subsection{Ig class determination and purification of antibodies}

The class of the secreted antibodies was determined initially by an Ouchterlony double diffusion test followed by biosynthetic labelling with ${ }^{35} \mathrm{~S}$-methionine as described earlier (16).

Monoclonal antibodies of the IgG subclasses were purified by chromatography on Protein A-Sepharose CL-4B (Pharmacia). Monoclonal antibodies of the IgM class were purified by ammonium sulphate precipitation followed by chromatography on a Sephacryl S-300 (Pharmacia) column (16).

\section{RESULTS}

3.1. Fusion frequency and antibody response

By immunizing the mice seven times, instead of three, prior to fusion (Table I) and increasing the cell number 3-fold, the fusion frequency was raised considerably. As judged by the number of wells containing growing hybridomas, it was raised from approximately $50 \%$ to $100 \%$. Contamination of some of the initial hybridomas in fusion $\mathrm{A}$ with bacteria did not allow us to detect more than a few antibody producing clones from this fusion. However, as judged by ELISA, 6.5\% of the clones resulting from fusion $B$ reacted with thylakoid membrane polypeptides. Of these initial clones, thirteen secreted antibodies to the 15.2 kD putative Fe-S centre protein, twelve produced antibodies to the chlorophyll $a$-protein 1 (17) and other lines secreted antibodies to polypeptides in the $30-35 \mathrm{kD}$ range. No hybridoma from fusion B, where PSI particles were the immunogen, produced antibodies to the $18.3 \mathrm{kD}$ protein.

Only in fusion $\mathrm{A}$, where the antigen was obtained from chloroform/methanol extracted thylakoids, did we score one hybridoma that secreted antibodies to the $18.3 \mathrm{kD}$ putative $\mathrm{Fe}-\mathrm{S}$ centre protein. This clone produced antibodies of the IgM class as determined by the Ouchterlony double diffusion test and biosynthetic labelling. Two hybridomas producing antibodies to the $15.2 \mathrm{kD}$ Fe-S centre protein were em-

Table 1.

Immunization schedules

Injections of thylakoid polypeptides

from C/M PBS-wash prior to fusion A
Injections pf PSI particles

prior to fusion $B$

$\begin{array}{ll}84 \mu \mathrm{g} \text { in FCA } & \text { Day0 } \\ 84 \mu \mathrm{g} \text { in FIA } & \text { Day 18 } \\ 17 \mu \mathrm{g} \text { in FIA } & \text { Day 39 } \\ \text { Tail-bleeding } & \text { Day 46 } \\ 17 \mu \mathrm{g} \text { in PBS } & \text { Day 50 } \\ 168 \mu \mathrm{g} \text { in PBS } & \text { Day 53 } \\ 336 \mu \mathrm{g} \text { in EB } & \text { Day } 54 \\ 252 \mu \mathrm{g} \text { in EB } & \text { Day 56 } \\ \text { Fusion } & \text { Day 57 }\end{array}$

FCA: Freund's complete adjuvant, FIA: Freund's incomplete adjuvant

EB: elution buffer, $10 \mathrm{~mm}-\mathrm{Tris}-\mathrm{HCl} \mathrm{pH} 7.6,200 \mathrm{~mm}-\mathrm{NaCl}, 0.1 \%$ Triton $\mathrm{X}-100$ 


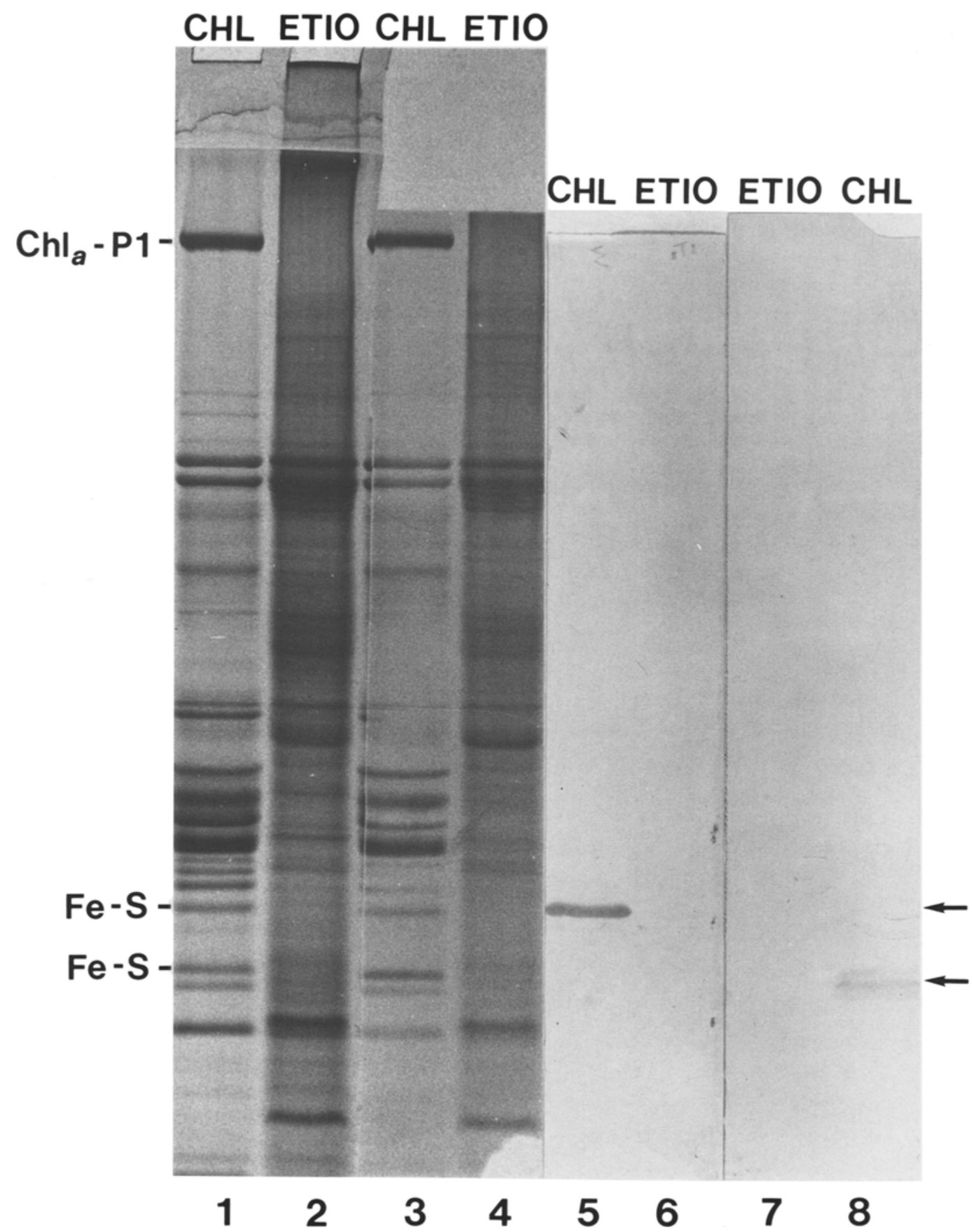

Figure 1. Presence of the putative Fe-S centre proteins in barley chloroplasts and etioplasts.

Chloroplasts $(20 \mu \mathrm{g}$ chlorophyll $\sim 100 \mu \mathrm{g}$ protein) and etioplast membranes ( $370 \mu \mathrm{g}$ protein) were separated on 11-15\% SDS-PAGE. The separated polypeptides were transferred to nitrocellulose filter and then probed with monoclonal antibodies to the 15.2 and $18.3 \mathrm{kD}$ proteins. Lanes 1 and 2 : chloroplast and etioplast membrane polypeptides prior to transfer onto nitrocellulose filter. Lanes 3 and 4: protein left over in the SDS-gel after electrotransfer. Nitrocellulose filters with thylakoid polypeptides (lane 5) and etioplast polypeptides (lane 6) probed with the monoclonal antibody to the $18.3 \mathrm{kD}$ putative $\mathrm{Fe}-\mathrm{S}$ centre protein, lane 7 : etioplast polypeptides and lane 8: chloroplast membrane polypeptides probed with a monoclonal antibody to the $15.2 \mathrm{kD}$ putative Fe-S centre protein. 


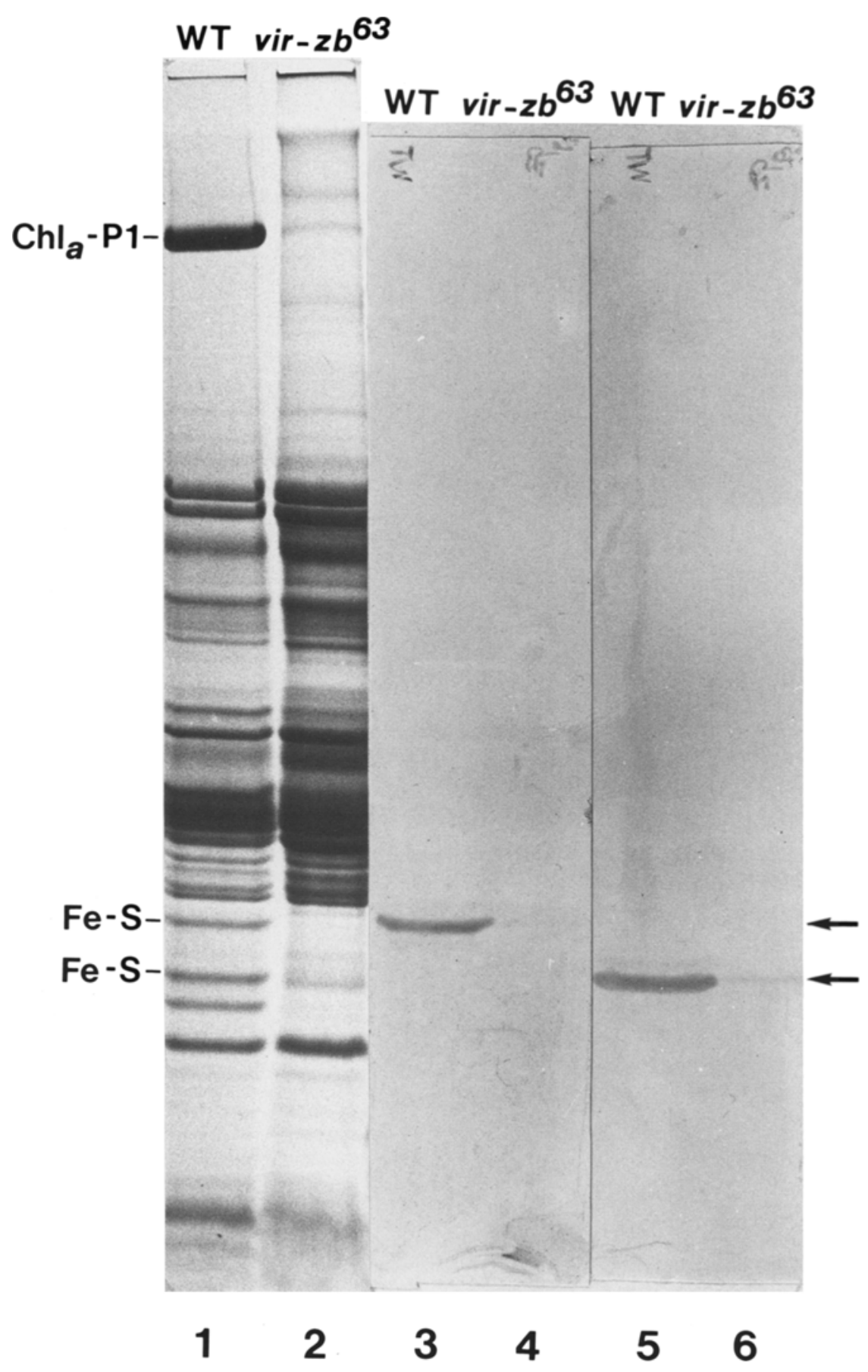

Figure 2. Test for the presence of the putative Fe-S centre proteins in thylakoids from wild-type and viridis- $z b^{63}$. Lane 1: wild-type thylakoid polypeptides (20 $\mu \mathrm{g}$ chlorophyll) and lane $2:$ viridis-z $b^{\mathrm{6s}}$ thylakoid polypeptides ( $20 \mu \mathrm{g}$ chlorophyll) separated on 11-15\% SDS-PAGE. The separated polypeptides were transferred to nitrocellulose filters which were used in immune-blot assays. Lane 3: wild-type thylakoid polypeptides and lane 4: viridis- $z b^{63}$ probed with the antibody to the $18.3 \mathrm{kD}$ polypeptide. Lane 5: wild-type and lane 6: viridis- $z b^{63}$ thylakoid polypeptides reacted with an antibody to the $15.2 \mathrm{kD}$ protein. 


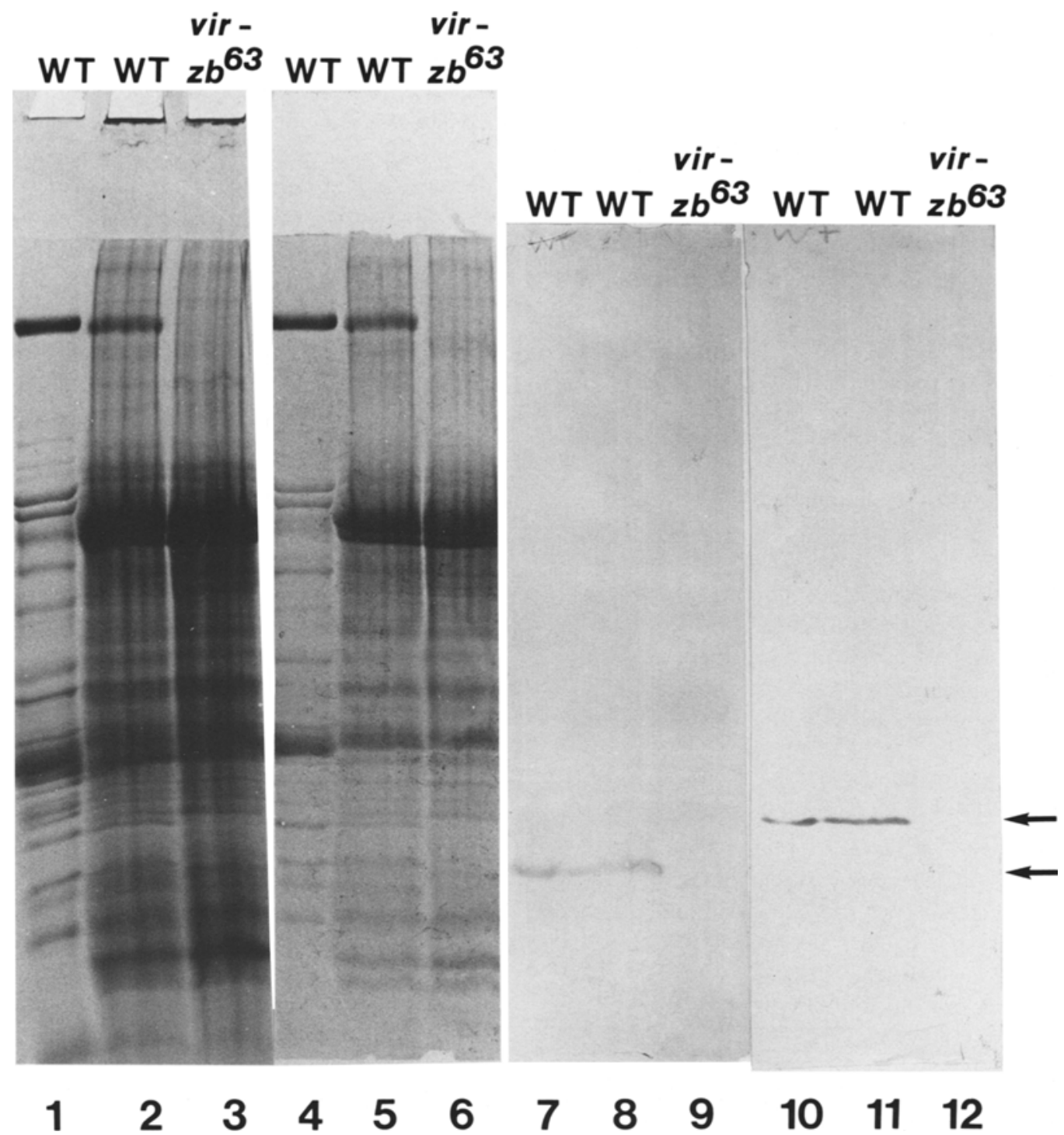

Figure 3. Test for the presence of the putative Fe-S centre proteins in protoplasts from wild-type and viridis-z $z b^{63}$.

Lane 1: solubilised polypeptides of purified wild-type thylakoids, lane 2: solubilised polypeptides of wild-type protoplasts and lane 3: polypeptides of protoplasts from viridis- $z b^{63}$ were separated on $11-15 \%$ SDS-PAGE. The polypeptides were transferred to nitrocellulose filters. Lanes 4, 5, 6 show protein left over in the gel after electrotransfer. Lanes 7, 8, 9: the filter was probed with a monoclonal to the $15.2 \mathrm{kD}$ protein and in lanes $10,11,12$ : the filter was probed with the monoclonal antibody to the $18.3 \mathrm{kD}$ protein.

ployed in this study. One of the lines secreted antibodies of the IgM and other of the IgG class. After initial specificity identification, all three hybridomas were cloned by limited dilution before they were used in immune-blot assays.
3.2. Are the putative Fe-S centre proteins present in etioplasts from wild-type and chloroplasts from wild-type and viridis$z b^{63}$ ?

$P 700$ activity has been observed in bean leaves after only 1 hour of greening (2). This 
implies a rapid light-induced synthesis of the polypeptides involved in PSI activity, if these polypeptides are not already present in etioplast internal membranes. Figure 1 shows an immune-blot assay where internal membrane polypeptides from chloroplasts and etioplasts were the antigens. When the nitrocellulose filters were probed with the monoclonal antibodies, bands were always observed among chloroplast polypeptides in the positions of the Fe-S centre proteins (Figure 1, lanes 5 and 8). No reaction with an etioplast membrane polypeptide was observed with our monoclonal antibodies (Figure 1, lanes 6 and 7). In Figure 1 approximately 4 times as much etioplast as chloroplast membrane protein was applied to the SDS-gel. Even when only $5 \mu \mathrm{g}$ of chlorophyll $(\sim 25 \mu \mathrm{g}$ of protein) was used, the two polypeptides are easily detected in chloroplast membranes. Thus, the concentration of the $18.3 \mathrm{kD}$ and $15.2 \mathrm{kD}$ putative $\mathrm{Fe}-\mathrm{S}$ centre proteins in etioplast internal membranes is less than $1 / 16$ of that in chloroplast membranes. This is consistant with the results of BALTIMORE and MALKIN, who were unable to detect the membrane-bound Fe-S centres in barley etioplasts by EPR spectroscopy at $15 \mathrm{~K}$ (3).

The nuclear gene mutant viridis- $z b^{63}$ shows a complete absence of PSI activity as measured both by in vitro electron transport reactions (13) and by fluorescence induction kinetics (34). Judged from electrophoretograms the mutant is lacking chlorophyll $a$-protein 1, the 18.3 and $15.2 \mathrm{kD}$ putative $\mathrm{Fe}-\mathrm{S}$ centre proteins and a polypeptide of apparent molecular weight 14,800 (13). Therefore, it was of interest to establish if it was possible to detect the two proteins in the thylakoids of the mutant by immune-blot assay. In Figure 2 nitrocellulose filters with thylakoid polypeptides from wildtype and viridis- $z b^{63}$ were probed with the monoclonal antibodies to the 18.3 and $15.2 \mathrm{kD}$ proteins. Where polypeptides from viridis- $z b^{6.3}$ were the antigens, both the $18.3 \mathrm{kD}$ (Figure 2, lane 4) and the and the $15.2 \mathrm{kD}$ antibody showed a weak reaction with polypeptides of these apparent molecular weights (Figure 2, lane 6). This demonstrates that small amounts of the 18.3 and $15.2 \mathrm{kD}$ putative $\mathrm{Fe}-\mathrm{S}$ centre protein are present in viridis- $z b^{63}$ thylakoids.
This result could indicate that the two proteins were synthesized but not inserted into the membranes of viridis- $z b^{63}$. If this were the case, these polypeptides might be detected in a higher concentration in whole protoplasts. Protoplasts from wild-type and viridis- $z b^{63}$ were isolated and after separation of their polypeptides on an SDS-gel they were transferred to nitrocellulose filters, which were used in an immune-blot assay (Figure 3). Although both the 18.3 and $15.2 \mathrm{kD}$ proteins were easily detected in wild-type protoplasts (Figure 3, lanes 8 and 11), no reaction was seen when the antigens were viridis-z $z b^{63}$ protoplast polypeptides (Figure 3, lanes 9 and 12). Thus, the concentration of the 18.3 and $15.2 \mathrm{kD}$ polypeptides in protoplasts is lower than in purified thylakoids of the mutant. The result, however, does not allow us to decide whether there is synthesis of the putative Fe-S centre proteins followed by a rapid breakdown, or if only very small amounts of these proteins are synthesized in viridis- $z b^{63}$.

\subsection{Identification of electroeluted 18.3 and $15.2 \mathrm{kD}$ polypeptides by immune-blot assay}

The purification of the two putative Fe-S centre proteins was attempted by electroelution. Thylakoid polypeptides were separated in an 8 $\mathrm{mm}$ thick slab gel and electrophoresed into the wells of an electroelution apparatus to be described elsewhere (19). The method is convenient, but might degrade the protein due to the heat evolved at the anode during electroelution. The electrophoretic mobility of the isolated polypeptides can change after such an electroelution, as shown for the $\alpha$-subunit of the chloroplast coupling factor, $\mathrm{CF}_{1},(19)$. Therefore, the initial identification on analytical SDS-gels of the two putative Fe-S centre proteins was verified by immune-blot assays.

In Figure 4A an electroeluted polypeptide of an apparent molecular weight of $18.3 \mathrm{kD}$ was the antigen. Only $1.5 \mu \mathrm{g}$ of protein was applied on the gel (Figure 4A, lane 6). This was electroblotted to nitrocellulose filters. Although not all $1.5 \mu \mathrm{g}$ of the $18.3 \mathrm{kD}$ polypeptide was transferred (Figure 4A, lane 4) enough was transferred to 


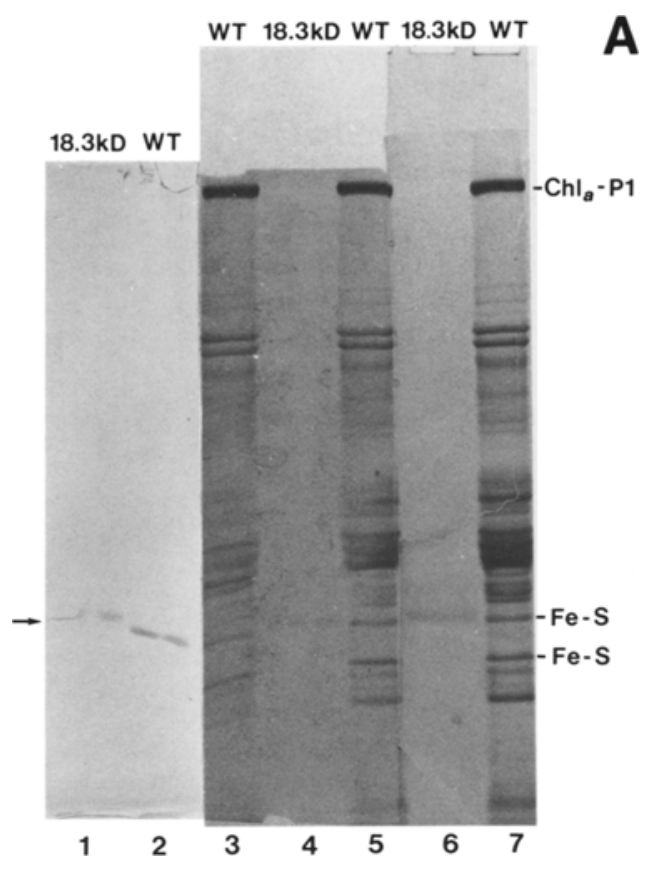

WT $15.2 \mathrm{kD}$ PSI WT $15.2 \mathrm{kD}$ PSI

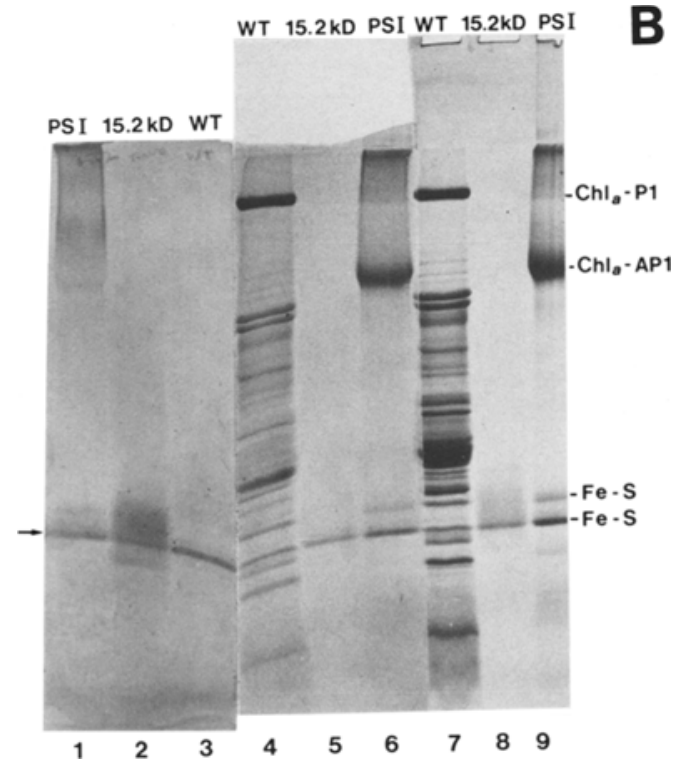

Figure 4. Identification of purified putative Fe-S centre proteins.

The two putative iron-sulphur centre proteins were purified by electroelution and then run on $11-15 \%$ SDS-PAGE. After transfer to nitrocellulose filters these were probed with the respective monoclonal antibodies. A: Lane l: purified $18.3 \mathrm{kD}$ polypeptide; lane 2: wild-type thylakoid polypeptides probed with the $18.3 \mathrm{kD}$ polypeptide antibody. Lanes $3,4,5$ : gel after electrotransfer. Lane 6: $1.5 \mu \mathrm{g}$ purified $18.3 \mathrm{kD}$ poly- react with the monoclonal antibody to the 18.3 $\mathrm{kD}$ protein. The non-uniform band in Figure $4 \mathrm{~A}$, lane 1 is due to an air bubble between the SDS-gel and the nitrocellulose filter.

The purified $15.2 \mathrm{kD}$ polypeptide produced a broad diffuse zone, which was terminated by a sharp band on the SDS-gel (Figure 4B, lane 8) of the same electrophoretic mobility as the $15.2 \mathrm{kD}$ putative $\mathrm{Fe}-\mathrm{S}$ centre protein in purified PSI particles and thylakoids (Figure 4B, lanes 7 and 9). In this experiment $4.5 \mu \mathrm{g}$ of $15.2 \mathrm{kD}$ polypeptide was applied. The diffuse zone of the polypeptide transferred with greater efficiency than the sharp band (Figure 4B, lane 5) as judged from the stainable protein in the gel after electro-blotting. The diffuse zone reacted with the monoclonal antibody to the $15.2 \mathrm{kD}$ protein, while the transferred sharp band and the $15.2 \mathrm{kD}$ protein in thylakoid and PSI particle polypeptide patterns reacted strongly (Figure 4B, lanes 1, 2 and 3). We considered this a definitive identification of the electroeluted putative $\mathrm{Fe}-\mathrm{S}$ centre proteins, and determined their amino acid composition. Because Tris, in the electroelution buffer, produces a peak in the same position as histidine one $\mathrm{ml}$ samples were dialysed against $500 \mathrm{ml}$ glass-distilled water twice, first 2 and then 18 hours before amino acid analysis. It was of interest to compare the two polypeptides for similarities in amino acid composition. Table II shows that there are distinct differences in the amounts of serine, glycine and histidine. Furthermore, the molecular weights of the two putative Fe-S centre proteins are higher, $21.3 \mathrm{kD}$ and $18.2 \mathrm{kD}$, respectively, when determined from their amino acid composition, than when estimated on the basis of electrophoretic mobility in SDS-PAGE.

peptide, and lane 7: thylakoid polypeptides $(20 \mu \mathrm{g}$ chlorophyll) prior to electrotransfer. B: Lane 1: PSI particle, lane 2: purified $15.2 \mathrm{kD}$ polypeptide, lane 3: wild-type thylakoid polypeptides probed with a monoclonal antibody to the 15.2 putative Fe-S centre protein. Lanes 4, 5, 6: gel after electrotransfer. Lane 7: thylakoid polypeptides ( $20 \mu \mathrm{g}$ chlorophyll), lane 8: $4.5 \mu \mathrm{g}$ purified $15.2 \mathrm{kD}$ polypeptide, and lane 9: 40 $\mu \mathrm{g}$ protein of PSI particles separated on SDS-PAGE prior to electrotransfer. 
Table II.

The amino acid composition of the putative Fe-S centre proteins associated with PSI.

\begin{tabular}{|c|c|c|}
\hline Residue & $\begin{array}{l}21.3 \mathrm{kD} \text { Fe-S centre protein } \\
\text { No." } / 21,3^{2} \mathrm{kD}\end{array}$ & $\begin{array}{l}18.2 \mathrm{kD} \mathrm{Fe}-\mathrm{S} \text { centre protein } \\
\text { No. }{ }^{\prime \prime} / 18,2^{31} \mathrm{kD}\end{array}$ \\
\hline Asx & 17 & 15 \\
\hline Thr & 8 & 10 \\
\hline Ser & 19 & 9 \\
\hline Glx & 24 & 20 \\
\hline Pro & 11 & 13 \\
\hline Gly & 31 & 19 \\
\hline Ala & 18 & 20 \\
\hline Val & 12 & 14 \\
\hline Met & 2 & 2 \\
\hline Ile & 9 & 6 \\
\hline Leu & 16 & 12 \\
\hline Tyr & 2 & 3 \\
\hline Phe & 9 & 6 \\
\hline His & 10 & 2 \\
\hline Lys & 9 & 11 \\
\hline Arg & 8 & 9 \\
\hline Cys & n.d. & n.d. \\
\hline Trp & n.d. & n.d. \\
\hline Total amino acids: & 205 & 171 \\
\hline
\end{tabular}

" 24 hours hydrolysis. Uncorrected for loss of threonine and serine

2) based on 16 leucine per molecule

${ }^{37}$ based on 12 leucine per molecule

\section{DISCUSSION}

The introduction of cell fusion for the production of antigen-specific monoclonal antibodies by KÖHLER and MILSTEIN (23) has considerable improved the possibility to obtain specific antibodies to a wide variety of antigens. The method has proven especially successful for surface antigens of cells and viruses, whereas antibodies to soluble antigens have been obtained with much greater difficulty (36). Therefore, one would expect that surface exposed antigenic sites on the PSI particle would elicit good antibody response. From experiments with trypsin-treated thylakoids (27), we know that parts of chlorophyll $a$-protein 1 is exposed at the thylakoid surface, since the electrophoretic mobility increases after trypsin-treatment. In fusion B (Table I) twelve independent hybridoma clones secreting antibodies to chlorophyll $a$-protein 1 were isolated (17). Furthermore, since we obtained thirteen different clones pro- ducing antibodies to the $15.2 \mathrm{kD}$ polypeptide, we conclude that this protein must also have some antigenic sites exposed on the thylakoid surface. In contrast, the $18.3 \mathrm{kD}$ protein did not stimulate an antibody response when it was presented to the mouse in a PSI particle. Only when present in polypeptide preparations where the lipids have been removed, did the $18.3 \mathrm{kD}$ polypeptide elicit an antibody response (15). This indicates that the $18.3 \mathrm{kD}$ protein is buried in the lipid matrix of the thylakoid membrane.

In addition to the polypeptide components of the PSI particle, a $14.8 \mathrm{kD}$ polypeptide is reduced or missing in all PSI mutants of barley (13, 29, 31). In Chlamydomonas mutants chlorophyll $a$-protein 1 and a specific set of at least six polypeptides (designated 20, 21, 28, 30, 35 and 37) are affected (9). The electrophoretic mobility and chloroform/methanol solubility of polypeptides 20 and 21 indicate that these polypeptides correspond to the two putative Fe-S 
centre proteins in barley $(9,15)$. With the aid of inhibitors these polypeptides have been shown in Chlamydomonas to be synthesized in the cytosol (5). In barley it has been shown by immunoprecipitation with monoclonal IgG's of in vitro translated polypeptides, that the 15.2 $\mathrm{kD}$ protein is nuclear coded (HøYER-HANSEN, HøJ and HøNBERG, unpublished). Chlorophyll $a$-protein 1 , in contrast, is chloroplast coded $(5,35,38)$.

The consistent pleiotropic nature of PSI mutants in barley (13) and in Chlamydomonas (9) suggests that the assembly of PSI in the thylakoid membrane requires the presence of all its constituents. Studies with the cold-sensitive barley mutant tigrina $\mathrm{O}^{34}$ confirm this. This mutant has unstable chloroplast ribosomes at the restrictive temperature (18). Thus, polypeptides known from other species to be synthesized on chloroplast ribosomes, are present in reduced amounts if not completely missing. In addition, the amount of the 18.3 and $15.2 \mathrm{kD}$ polypeptides is reduced at the restrictive temperature, and there is a clear increase in the amount of these, as well as chloroplast coded polypeptides, at the permissive temperature (18). In the PSI mutant viridis- $z b^{63}$, which has chloroplast ribosomes, a mutation in a nuclear gene prevents the accumulation of the chlorophyll $a$-protein 1 in the thylakoid membrane.

Interestingly, we were able to detect small amounts of the 15.2 and $18.3 \mathrm{kD}$ polypeptides in the thylakoid membranes of the PSI mutant viridis- $z b^{63}$. With the monoclonal antibodies currently available, no chlorophyll $a$-protein 1 was detected in purified thylakoids of this mutant. To determine if the polypeptide constituents of the PSI particle are transcribed in viridis$z b^{63}$, immunoprecipitations of polypeptides translated in vitro from RNA isolated from the mutant are needed and such studies are in progress.

\section{ACKNOWLEDGEMENTS}

We wish to thank Professor DITER vON WETTSTEIN for continuing encouragement and a critical review of the manuscript. We are grateful to TOM BEKTVED for excellent technical assistance. Dr. IB SVENDSEN and BODIL
CORNELIUSSEN are thanked for carrying out amino acid analyses. We wish to thank ANNSOFI STEINHOLZ for photographic work and NINA RASMUSSEN for preparing the figures. We are grateful to HANNE THEM NIELSEN and LISE TRILLOT for typing the manuscript.

\section{REFERENCES}

1. ARNon, D.I.: Copper enzymes in isolated chloroplasts. Polyphenoloxidase in Beta vulgaris. Plant Physiol. 24, 1-14 (1949)

2. BAKER, N.R.\& W.L. BUTLER: Development of the primary photochemical apparatus of photosynthesis during greening of etiolated bean leaves. Plant Physiol. 58, 526-529 (1976)

3. BALtimore, B.G. \& R. MALKIN: Appearance of membrane-bound iron-sulfur centers and the photosystem I reaction center during greening of barley leaves. Plant Physiol. 60, 76-80 (1977)

4. Chua, N.-H.\&. Bennoun: Thylakoid membrane polypeptides of Chlamydomonas reinhardtii: Wild-type and mutant strains deficient in photosystem II reaction center. Proc. Nat. Acad. Sci., USA, 72, 2175-2179 (1975)

5. ChuA, N.-H. \& N.W. Gillham: The sites of synthesis of the principal thylakoid membrane polypeptides in Chlamydomonas reinhardtii. J. Cell Biol. 74, 441-452 (1977)

6. EDWARDS, G.E., S.P. Robinson, N.J.C. TYLER \& D.A. WALKER: Photosynthesis by isolated protoplasts, protoplast extracts and chloroplasts of wheat. Influence of orthophosphate, pyrophosphate, and adenylates. Plant Physiol. 62, 313-319 (1978)

7. EvaNS, M.C.W.: Electron paramagnetic resonance studies in photosynthesis. In: Primary Processes of Photosynthesis (J. Barber, ed.) Elsevier/North Holland, Biomedical Press, Amsterdam, pp. 433464 (1977)

8. Fazekas de St. Groth, S. \& D. Scheidegger: Production of monoclonal antibodies: Strategy and Tactics. J. Immunol. Meth. 35, 1-21 (1980)

9. Girard, J., N.H. Chua, P. Bennoun, G. Sch. MIDT \& M. DelosmE: Studies on mutants deficient in the photosystem I reaction centers in Chlamydomonas reinhardtii. Curr. Genet. 2, 215-221 (1980)

10. GOLBECK, J.H. \& B. KoK: Further studies of the membrane-bound iron-sulfur proteins and P700 in photosystem I subchloroplast particle. Arch. Biochem. Biophys. 188, 233-242 (1978)

11. Graham, R.C. JR., U. Lundholm \& M.J. Kak NOVSKY: Cytochemical demonstration of Feroxi- 
dase activity with 3-amino-9-ethylcarbazole. J. Histochem. Cytochem. 13, 150-153 (1965)

12. HeathCote,P., K.N. Timofeev \& M.C.W.Evans: Detection by EPR spectrometry of a new intermediate in the primary photochemistry of photosystem I particles isolated using Triton X-100. FEBS Lett. 101, 105-109 (1979)

13. Hiller, R.G., B.L. Møller \& G. Høyer-Hansen: Characterization of six putative photosystem I mutants in barley. Carlsberg Res. Commun. 45, 315-328 (1980)

14. Hoarau, J., R. Remy \& J.-C. Leclerc: Hétérogénéité des variations spectrales photoinduites vers $700 \mathrm{~nm}$ observées sur les membranes chlorophylliennes et les complexes chlorophylle-protéines isolés de divers organismes photosynthetiques. Biochim. Biophys. Acta 462, 659-670 (1977)

15. HønberG, L.S.: Monoclonal antibodies to $23 \mathrm{kD}$ and $18.3 \mathrm{kD}$ barley thylakoid polypeptides. In: Advances in Photosynthesis Research, C. Sybesma ed., M. Nijhoff/Dr. W. Junk Publishers, The Hague, The Netherlands, Vol. IV, pp. 525-528 (1984)

16. Hønberg. L.S.: Probing barley mutants with a monoclonal antibody to a polypeptide involved in photosynthetic oxygen evolution. Carlsberg Res. Commun. 49, 703-719 (1984)

17. HøyER-Hansen, G.: Monoclonal antibodies to chlorophyll $a$-protein 1 in barley. In: Advances in Photosynthesis Research, C. Sybesma ed., M. Nijhoff/Dr. W. Junk Publishers, The Hague, The Netherlands, Vol. III, pp. 171-174 (1984)

18. Høyer-Hansen, G. \& G. Casadoro: Unstable chloroplast ribosomes in the cold-sensitive barley mutant tigrina- $0^{34}$. Carlsberg Res. Commun. 47, 103-118 (1982)

19. Høyer-Hansen, G., L.S. Hønberg, C.G. KanNangara, S.P. Gough, F. Uebel \& J.N. RasMUSSEN: Purification and identification of the $\alpha$-subunit of chloroplast coupling factor using a novel electroelution apparatus and a monoclonal antibody. In preparation

20. Høyer-Hansen, G., B.L. Møller \& L.C. Pan: Identification of coupling factor subunits in thylakoid polypeptide patterns of wild-type and mutant barley thylakoids using crossed immunoelectrophoresis. Carlsberg Res. Commun. 44, 337-351 (1979)

21. Høyer-Hansen, G. \& D.J. Simpson: Changes in the polypeptide composition of internal membranes of barley plastids during greening. Carlsberg Res. Commun. 42, $379-389$ (1977)

22. KEARNEY, J.F., A. RADBRUCH, B. LIESEGANG \& K. RAJEWSKY: A new mouse myeloma cell line that has lost immunoglobulin expression but permits the construction of antibody-secreting hybrid cell lines. J. Immunol. 123, 1548-1550 (1979)

23. Köhler, G. \& C. Milstein: Continuous cultures of fused cells secreting antibody of predefined specificity. Nature 256, $495-497$ (1975)

24. Lagoutte, B., P. Setif \& J. Duranton: Tentative identification of the apoproteins of the iron-sulfur centers of photosystem I. FEBS Lett. 174, 24-29 (1984)

25. LOWRY,O.H., N.J.ROSEBROUGH, A.L.FARR \& R.J. RANDALL: Protein measurement with the Folin phenol reagent. J. Biol. Chem. 193, 265-275 (1951)

26. MACHOLD, O.: Interspecies heterogeneity of thylakoid proteins as exemplified by cytochrome $f$. Photobiochem. Photobiophys. 7, 287-292 (1984)

27. Machold, O., D.J. Simpson \& G. Høyer-HaNSEN: Correlation between the freeze fracture appearance and polypeptide composition of thylakoid membranes in barley. Carlsberg Res. Commun. 42, $499-516$ (1977)

28. Mathis, P., K. Sauer \& R. Remy: Rapidly reversible flash-induced electron transfer in a $P-700$ chlorophyll-protein complex isolated with SDS. FEBS Lett. 88, 275-278 (1978)

29. Møller, B.L., G. Høyer-HANSEN \& R.G. Hiller: Functional identification of barley thylakoid polypeptides resolved by SDS-polyacrylamide gel electrophoresis. In: G. Akoyunoglou ed., Photosynthesis III. Structure and Molecular Organisation of the Photosynthetic Apparatus. Balaban Int. Services, Philadelphia, Pa. 1981, pp. 245-256

30. Møller, B.L., J.H.A. Nugent \& M.C.W. Evans: Electron paramagnetic resonance spectrometry of photosystem I mutants in barley. Carlsberg Res. Commun. 46, 373-382 (1981)

31. Møller, B.L. R.M. SMillie \& G. Høyer-HaNSEN: A photosystem I mutant in barley (Hordeum vulgare L). Carlsberg Res. Commun. 45, 87-99 (1980)

32. Schreier, M., G. Köhler, H. Hengartner, C. Berek, T. Trucco, L. Forni, T. Staehelin, J. STOCKER \& B. TAKACS: Hybridoma techniques, EMBO, SKMB Course 1980, Basel

33. Shulman, M., C.D. Wilde \& G. Köhler: A better line for making hybridomas secreting specific antibodies. Nature 276, 269-270 (1978)

34. Simpson, D.J. \& D. von WeTtStein: Macromolecular physiology of plastids. XIV. Viridis mutants in barley: Genetic, fluoroscopic and ultrastructural characterization. Carlsberg Res. Commun. 45, 283-314 (1980)

35. SMith, A.G. \& J.C. GRAY: Localization of the gene for P700 chlorophyll $a$ protein in pea chloroplast 
DNA. Mol. Gen. Genet. 194, 471-476 (1984)

36. Stähli, C., T. Staehelin, V. Miggiano, J. SCHMIDT \& P. HÄrING: High frequencies of antigen-specific hybridomas: Dependance on immunization parameters and prediction by spleen cell analysis. J. Immunol. Meth. 32, 297-304 (1980)

37. Towbin, H., Staehelin, T. \& J. GoRdon: Electrophoretic transfer of proteins from polyacrylamide gels to nitrocellulose sheets: Procedure and some applications. Proc. Nat. Acad. Aci., USA 76, 43504354 (1979)

38. Westhoff, P., J. Alt, N. Nelson, W. BottomLey, H. Bünemann \& R.G. HerrmanN: Genes and transcripts for the $\mathrm{P}_{700}$ chlorophyll $a$ apoprotein and subunit 2 of the photosystem I reaction center complex from spinach thylakoid membranes. Plant Mol. Biol. 2, 95-107 (1983)

Accepted by: H. Klenow, E. Lund and S.O. ANDERSEN 